\title{
A Note on the Demographics of UK Referendums on "Staying or Leaving the European Union"
}

\author{
Alice A. Melkumian \\ Western Illinois University
}

This article discusses the history of the United Kingdom as a member of the European Union. It looks at the demographics of the votes for 1975 and 2016 Referendums on the membership in the Union. I find that changing demographic trend - the aging of the UK population - is the reason for the "Leave the Union" majority vote in 2016 Referendum.

\section{INTRODUCTION}

In 1973 the United Kingdom application to join the European Economic Community (ECC) was approved by the ECC. The news was celebrated throughout the country with spirit-lifting speeches and torches. The membership expected to bring prosperity, enrichment of information, and knowledge to the United Kingdom (UK), boost the efficiency and competiveness of UK trading relationships, and increase the UK accessibility of other European and world markets. Two years later, in 1975, when Labor party came to power the question "Stay or Leave the ECC" was answered by the UK referendum as follows: $68 \%$ of all voters wanted to stay, and $32 \%$ of the voters wanted to leave. Two thirds of the voters were ecstatic and ready for a new life to begin.

43 years after joining the European Community, in June of 2016, the UK referendum showed that $52 \%$ of the voters choose to leave the European Union (EU). What has driven the majority of the UK voting population to want to leave the EU after almost a generation of being a part of the union? Was this vote influenced by generational difference, educational differences, regional differences, political differences? Was it a combination of some or all of it?

In this paper I analyze the demographic aspect of the UK vote to exit the EU in 2016 with that of the UK to stay in the EU in 1975.

I find that the aging of the UK population, the increase in the portion of the UK population of 65 years of age and older is the reason the Referendum vote turned to be "Leave" and not "Stay".

\section{LITERATURE REVIEW}

A monetary union of several countries assumes a merger (integration) of the countries' economies and a change in the countries' political views and actions. Is it beneficial to become a member of such a union? Are there costs to incur from such a union? Answers to these two questions are the basis for the decision to join or leave the union. The following literature (and the list presented here is not exhaustive) is researching these two questions. Campos at al. (2014) found that without deep economic and political 
integration into the monetary union income per capita of the country-members will suffer a negative impact. Gasiorek, Smith, and Venebles (2012) showed there is a potentially large welfare impact in countries-members of the union due to imperfect competition. Minford (2006) calculated economic costs of EU membership for UK and the rest of the members and suggested that political integration of the union is the priority over economic efficiency. Pain and Young (2004) argued that should the UK decides to leave the union its living standards will be negatively affected mostly due to the fall of incoming foreign direct investments. Ottaviano at al. (2014) estimated that GDP static losses of the UK once out of the EU are quite large. Mansfield (2014) argued that leaving EU would be extremely beneficial for the UK trade - when is not part of the union UK can direct its trade to the emerging markets where the majority of the growth is located. Dustmann and Tomasso (2013) found that immigration produces a slight positive increase in natives' wages.

The majority of these findings lead us to believe that joining a monetary union is economically beneficial. And it will be safe to assume that these expected benefits were the reason for the overwhelming vote to join the union in 1975. Now we fast forward to 2016 and to the UK referendum of 2016 on "Stay or Leave the EU". Even though the referendum is a very recent event, there is a large volume of published research evaluating the results of the referendum vote. In explaining the results of the referendum Goodwin and Heath (2016), Menon and Salter (2016), Heppel, Crines, and Jeffery (2017) looked at education level, occupation, age, immigration status, and ethnic diversity of voters, political and ideological variables. Coleman (2016) brought up the issues of sovereignty and immigration. Harris and Charlton (2016) discussed the geographical spread of "Stay" versus "Leave" votes. Vasilopoulou (2016) in discussion of the possible referendum outcomes brought in high levels of citizens' uncertainty, lack of unity in political parties. Menon and Fowler (2016) suggested that discussion of the connection of the UK and the EU will still be present in political and economic debates even after the referendum. Van Reenen (2016) and Sampson (2017) expect higher trading costs with the rest of EU and welfare losses (dynamically increasing up to $9.5 \%$ ) after the separation takes place.

\section{WHY VOTE TO “LEAVE" WHEN THERE ARE SO MANY BENEFITS OF BEING A MEMBER OF THE UNION?}

What we are seeing here is a contradiction between the empirical findings of the Union membership benefits and the actions of the UK population in 2016 voting to exit the European Union.

Let us have a brief look at how the United Kingdom voted in 1975 to stay or to exit the European Economic Community.

TABLE 1

DEMOGRAPHIC PROFILE OF REFERENDUM VOTING IN 1975 BY AGE (VOTERS ONLY)

\begin{tabular}{|l|c|c|c|c|c|}
\hline & $\mathbf{1 8 - 3 4}$ & $\mathbf{3 5 - 4 4}$ & $\mathbf{4 5 - 5 4}$ & $\mathbf{6 5 -}$ & All Age Group Combined \\
\hline Yes (stay) & 68 & 65 & 69 & 70 & 68 \\
\hline No (leave) & 32 & 35 & 31 & 30 & 32 \\
\hline & $100 \%$ & $100 \%$ & $100 \%$ & $100 \%$ & $100 \%$ \\
\hline
\end{tabular}

Table 1 shows that a considerable majority of the voting population (regardless of age) was in favor of staying in the European Economic Community (that later became the European Union). The margins between "yes - to stay" voters and "no - to leave" voters are interestingly consistent through different demographic groups and is between $30 \%$ and $40 \%$. The voters of 65 years old presented the most decisive group of voters: $70 \%$ of these voters wanted to stay in the Union. The second strongest group of voters is 45-54 years old and is only one percentage point behind with $69 \%$ of voters expressing their wish to stay as a part of the Union. The percentage of voting participation in 1975 was about $63 \%$.

Table 2 presents the demographic profile of the UK Referendum in 2016. The age groups presented in the table are slightly different from those in Table 1. 
The percentage of voting participation in 2016 was about $72 \%$ - considering the size of the UK population - much higher than that in the Referendum vote in 1975 . The higher number of voters clearly states the importance of the Referendum to the population in 2016.

TABLE 2

DEMOGRAPHIC PROFILE OF REFERENDUM VOTING IN 2016 BY AGE (VOTERS ONLY)

\begin{tabular}{|l|c|c|c|c|c|}
\hline & $\mathbf{1 8 - 2 4}$ & $\mathbf{2 5 - 4 9}$ & $\mathbf{5 0 - 6 4}$ & $\mathbf{6 5 -}$ & All Age Group Combined \\
\hline Yes (stay) & 75 & 56 & 44 & 39 & 48.1 \\
\hline No (leave) & 25 & 44 & 56 & 61 & 51.9 \\
\hline & $100 \%$ & $100 \%$ & $100 \%$ & $100 \%$ & $100 \%$ \\
\hline
\end{tabular}

It is interesting to note that the overwhelming majority of the youngest voters (age 18 to 24) in 2016 wanted to stay ( $75 \%$ "Yes" to stay), and in 1975 only $68 \%$ of the youngest voters (age 18 to 34 ) showed interest in staying in EEC. 32\% of all voters in 1975 expressed the wish to exit the European Economic Community. This is quite a large part of the voting population. The possible explanation for these numbers is that back in 1975 nobody really knew what it would be like to be a part of a united zone with no borders, no currency exchanges (on the continent), with no visas to enter a country, with absolutely mobile work force and no restrictions on trade. And that "not knowing" factor kept the voters more on the caution side. Therefore, the "Yes" to stay in the EEC votes throughout the voting population was 68\% (all age groups combined). As we look at the 2016 Referendum votes we see that the youngest voters were absolutely determined to stay in the Union. Voters in the age group of 18-24 were born into the European Union and enjoyed the benefits of unification their entire life. For them, separating from the EU is going back in time, regressing into separation and isolation. The youngest voters in 1975 would currently (the year of 2016 vote) be in 61+ years of age group. And these voters will be captured in the last two columns of Table 2: age 50-64 and 65-. And these two columns show a very determined vote to leave the European Union (56\% and 61\% voted to leave the EU in the respective age groups of 50-64 and 65-). And I strongly believe that these two columns were the decision-making columns on the issue to "stay" or "leave" the Union.

These two last columns of Table 2 show a startling change in the opinion of the voters on the position of the UK in the European Union. This change suggests that what was happening to the UK as a member of the EU from 1973 to 2016 was not agreeable or expected by the population. It suggests that expectations of the young people voting "yes" to the unification in 1975 were not met. It suggests disappointment in and resentment towards the Union or the policies the UK had to adapt and follow as the Union member.

TABLE 3

AGE DISTRIBUTION OF THE UK POPULATION, 1975 - 2045 (PROJECTED)

\begin{tabular}{|lrccc|}
\hline Year & UK Population & 0 to 15 years $(\%)$ & 16 to 64 years $(\%)$ & 65 years and over $(\%)$ \\
\hline 1975 & $56,226,000$ & 24.9 & 61.0 & 14.1 \\
1985 & $56,554,000$ & 20.7 & 64.1 & 15.2 \\
1995 & $58,025,000$ & 20.7 & 63.4 & 15.8 \\
2005 & $60,413,000$ & 19.3 & 64.7 & 15.9 \\
2015 & $65,110,000$ & 18.8 & 63.3 & 17.8 \\
2025 & $69,444,000$ & 18.9 & 60.9 & 20.2 \\
2035 & $73,044,000$ & 18.1 & 58.3 & 23.6 \\
2045 & $76,055,000$ & 17.7 & 57.8 & 24.6 \\
\hline
\end{tabular}


If we look at the age distribution of the UK population (from the Office for National Statistics [GB]) presented in Table 3 we will find some interesting patterns. The portion of population of 65 years and older increased by $3.7 \%$ from 1975 to 2015 . And the portion of the population of 0 to 15 years of age decreased by $6.1 \%$ over the same time period.

From the same source we learn that "... the proportion of children in the UK population has declined from over 24\% in 1975 to less than 20\% in 2015." (Office for National Statistics [GB]). It is expected that this proportion will decline even further in the future. This data is the clear indicator of an aging trend of the UK population.

Let us look at the percentage difference between "No, we want to leave the EU" votes and "Yes, we want to stay in the EU" votes in 2016. There were only 3.8\% more voters who wanted to "leave" the EU than the voters who wanted to "stay" in the EU.

Now let us look at the percentage increase in the population group of 65+ years of age from 1975 to 2015. In 2015 there were 3.7\% more people in that age group than in 1975 . What we see here is a faster growth of older portion of the population, a faster growth of the age group that voted overwhelmingly to exit the EU in 2016. That extra 3.7\% of people of $65+$ years of age in 2015 brought extra $3.8 \%$ of "No, we want to exit the EU" to the voting places in 2016 and those extra votes decided the fate of the Referendum.

The conclusion I arrive at is the aging of the UK population, the increase in the portion of the UK population of 65 years of age and older is the reason the Referendum vote turned to be "Leave" and not "Stay".

\section{WHAT IS BEHIND THE "LEAVE THE EU" RATHER THAN "STAY IN THE EU" FOR THE OLDER/AGING UK POPULATION?}

The 65+ years of age voters in 2016 Referendum decision-making group were $22+$ years of age during the 1975 Referendum and were mostly in the youngest voting group of 18-34 year-old. The $68 \%$ of the 18-34 year-old voters in 1975 voted to "Stay in the EU". With the assumption that those same people in 2016 were $65+$ years of age, $61 \%$ of those same people in 2016 voted to "Exit the EU" in 2016. Why? What has changed in those people's perception of the EU over the 43 years of the UK tenure as a member of the EU?

The change in the vote from the "Stay in the EU" in 1975 to the "Exit the EU" in 2016 for this group sends a very strong signal of dislike, disapproval, dis-consent for the EU membership. It looks as if the 43 years of the EU membership did not inspire further support for the union, but undermined the belief in the union.

Being a part of the European Union means following a uniform (the same policy for all the countrymembers of the EU) immigration policy, following a uniform trading policy. Being a part of the Union means opening the borders to immigration, to free trade, to free flow (and outflow) of financial assets and capital. But it also means opening the border to risk. A step away from a contained, beneficial to the UK only policies to policies that were to benefit all the country-members of the union opens the border to uncertainty about the future - how would these new policies affect the UK? Will the new policies improve our welfare? Will the UK be a better (for consumers) country than it was before joining? It is obvious from the votes in 1975 that the population in its majority strongly believed in a better future with the EU. But through the 43 years of the EU membership that belief has disappeared. The uncertainty of future impacts on the UK economy through the uniform policies crates risk. The uncertainty is associated with future immigration policy, trade policy, the uncertainty of wages and welfare. The greater the future uncertainty the greater the risk, the less acceptable that future becomes. And as the UK membership extends into the future, the immigration, the trade, and the welfare will change unknowingly and unpredictably. The uncertainty of these future conditions - economic, political, individual - increases, and, therefore, the level of risk increases making aging portion of the population extremely uncomfortable as the Union country-member. And how does the aging (increasingly aging) portion of the population react to this increased risk? It dislikes it. It dislikes it extremely. 
2016 Referendum offers a choice to this portion of the population: to stay in the EU and experience that uncertainty or to leave, and become a country in its own, as before, before 1973 - the year of joining of the EEC. Both choices offer risk, but risk of different degrees. Going back to an independent country (like it ones has been) seems to offer relatively less risk (we have been an independent country before and we know how that works) than to continue as a member of the EU (something we do not know how will end). With age our ability to absorb risk changes. Palsson (1996), Wang and Hanna (1997), Pratt (1964), Sahm (2012), Steffensen (2011), Morin and Suarez (1983) found that as we age out relative risk aversion increases. And in deciding between the two risks the 65+ year olds in 2016 Referendum chose the lower risk of exiting the EU back to the independent UK.

\section{CONCLUSION}

The major reason the UK Referendum of 2016 "To stay in the European Union or to leave" was answered "To leave" is due to the aging of the UK population. There were only $3.8 \%$ more voters who wanted to "Leave" the EU than the voters who wanted to "Stay" in the EU. The $3.7 \%$ increase in $65+$ year-old voters in 2016 (comparing to the demographics of 1975) produced those decisive extra 3.8\% "Leave" votes. The major reason for the older voters choosing "To leave the EU" was their increasing degree of relative risk aversion to uncertainties brought into their lives by the membership in the European Union.

\section{REFERENCES}

Capmos, N.F., Coricelli, F. and Moretti, L (2014) "Economic Growth and Political Integration: Estimating the Benefits from Membership in the European Union Using the Synthetic Counterfactuals Method" Institute for the Study of Labor, IZA Discussion Paper, No. 8162.

Coleman, D. (2016) "A Demographic Rationale for Brexit" Population and Development Review, December 2016, 42, 681-92.

David Butler, Ume Kitzinger, The 1975 Referendum, McMillan Press LTD, 1996. Office for National Statistics [GB].

Dustmann, Christian, Tommaso Frattini, and Ian P. Preston (2013) "The Effect of Immigration along the Distribution of Wages." Review of Economic Studies, 80 ( 1 ), 145-73.

Eaton, Jonathan, and Samuel Kortum (2002) "Technology, Geography, and Trade." Econometńca, 70 (5), 1741-79.

Gasiorek, M., Smith, A. and Venebles, A.J. (2002) "The accession of the UK to the EC: A Welfare Analysis" Journal of Common Market Studies, 40 (3), 425-47.

Goodwin, M. J., Heath, O. (2016) "The 2016 Referendum, Brexit and the Left Behind: An Aggregatelevel Analysis of the Result" The Political Quarterly, 87 (3), July-September 2016, 323-332.

Harris, R., Charlton, M. (2016) "Voting Out of the European Union: Exploring the Geography of Leave: Commentary" Environment and Planning, November 2016, 48 (11), 2116-28.

Heppel, T., Crines, A., Jeffery, D. (2017) "The United Kingdom Referendum on European Union Membership: The Voting of Conservative Parliamentarians" Journal of Common Market Studies, 55 (4), $762-778$.

Mansfield, I. (2014) "A Blueprint for Britain: Openness not Isolation" Institute of Economic Affairs (IEA)

Mennon, A., Salter, John-Paul (2016) "Brexit: Initial Reflections" International Affairs, 92 (6), $1297-$ 1318.

Menon, A., Fowler, B. (2016) "Hard of Soft? The Politics of Brexit" National Institute Economic Review, Issue 238, 4-12.

Minford, P. (2006) "Measuring the Economic Costs and Benefits of the EU" Open economies review, 17 (4-5), 509-524. 
Morin, R. A., \& Suarez, A. F. (1983) "Risk aversion revisited." The Journal of Finance, 38 (4), 12011216.

Ottaviano, G. I., Pessoa, J.P., Sampson, T., Van Reenen, J. (2014) "The Costs and Benefits of Leaving the EU” Center for Financial Studies Working Paper Series, No. 472.

Pain, N., Young, G. (2004) "The Macroeconomic Impact of UK Withdrawal from the EU" Economic Modeling, 21 (3), 387-408.

Pålsson, A. M. (1996). "Does the degree of relative risk aversion vary with household characteristics?" Journal of economic psychology, 17 (6), 771-787.

Pratt, J. (1964) "Risk Aversion in the Small and in the Large." Econometrica, 32 (1/2), 122-136.

Reneen, John Van (2016) "Brexit's Long-Run Effects on the U.K. Economy", Brookings Papers on Economic Activity, Fall 2016, 367-383.

Sahm, C. R. (2012) "How much does risk tolerance change?" The Quarterly Journal of Finance, 2 (04), $1-38$.

Sampson, T. (2017) "Brexit: The Economics of International Disintegration", The Journal of Economic Perspectives, 31 (4), Fall 2017, 163-184.

Steffensen, M. (2011) "Optimal consumption and investment under time-varying relative risk aversion." Journal of Economic Dynamics and Control, 35 (5), 659-667.

Vasilopoulou, S. (2016) "UK Euroscepticism and the Brexit Referendum" The Political Quarterly, 87 (2), 219-227.

Wang, H., \& Hanna, S. (1997) "Does risk tolerance decrease with age?" Financial Counseling and Planning, 8 (2), 27-23. 